\title{
Phylogenetic relationship of Alexandrium tamiyavanichii (Dinophyceae) to other Alexandrium species based on ribosomal RNA gene sequences
}

\author{
Gires Usup*, Leaw C. Pin, Asmat Ahmad, Lim P. Teen \\ Program Sains Laut, Pusat Pengajian Sains Sekitaran dan Sumber Alam, Fakulti Sains dan Teknologi, \\ Universiti Kebangsaan Malaysia, 43600 Bangi, Selangor, Malaysia
}

Received 2 December 2001; received in revised form 12 January 2002; accepted 5 February 2002

\begin{abstract}
The phylogenetic relationship of the thecate PSP-toxin producing dinoflagellate Alexandrium tamiyavanichii Balech to other species of Alexandrium was studied based on nucleotide sequences of the ITS1, ITS2, 5.8S, 18S and 28S subunits of the ribosomal RNA gene. These are the first such sequences available for A. tamiyavanichii, which is one of the producers of paralytic shellfish poisoning toxins in tropical waters. Based on the nucleotide sequences of the 28S, $18 \mathrm{~S}$ and $5.8 \mathrm{~S}$ subunits of the rRNA gene, A. tamiyavanichii grouped together with A. tamarense, A. catenella and A. fundyense. More interestingly, A. tamiyavanichii was most closely affiliated to $A$. tamarense isolates from Thailand. This result reaffirmed conclusions from previous studies that, for the A.tamarenselfundyense/catenella species complex, geographical origin rather than morphology seems to determine genetic relatedness. Results of this study also suggest that A. tamiyavanichii most probably belongs to the same species complex. Ribosomal RNA gene sequences do not separate the PSP toxin producing from the non-producing species of Alexandrium. () 2002 Elsevier Science B.V. All rights reserved.
\end{abstract}

Keywords: Alexandrium tamiyavanichii; Phylogenetic relationship; Ribosomal RNA gene; Paralytic shellfish poisoning

\section{Introduction}

Several marine dinoflagellate species are known to produce toxins that cause paralytic shellfish poisoning (PSP). Most of these species belong to the thecate genus Alexandrium Halim. Pyrodinium bahamense Plate var. compressum Böhm is currently the only other thecate genus known to produce PSP

\footnotetext{
* Corresponding author. Present address: Fakulti Sains dan Teknologi Sumber, Universiti Malaysia Sarawak, 94300 Kota Samarahan, Sarawak, Malaysia. Tel.: +60-3-8929-3219; fax: +60-3-8925-3357.

E-mail address: gires@pkrisc.cc.ukm.my (G. Usup).
}

toxins, while of the athecate dinoflagellates only Gymnodinium catenatum Graham is currently known to cause PSP. In Malaysia and several other tropical Pacific countries, the most important PSP-toxin producing species is Pyrodinium bahamense var. compressum (Usup and Azanza, 1998). In the Straits of Malacca, however, there is evidence that PSP events there are due primarily to A. tamiyavanichii. Kodama et al. (1988) also previously reported the presence of $A$. tamiyavanichii in Thailand waters.

Alexandrium is arguably the most important harmful algal bloom (HAB) species, based on the number of species involved and their extensive geographical distribution. It is, thus, not surprising that many studies 